\title{
Key Tasks and Competences of Spatial Data Manager in Local Self-Government
}

\author{
Josip Lisjak*, Ante Rončević, Danko Markovinović
}

\begin{abstract}
The article addresses the spatial data manager domain in local self-government units. The scope of the article comprehends typical tasks and required competences for conducting the usual spatial data manager job tasks in local self-government. Furthermore, in the research described in the article, the tasks are systematized and mapped with required competences. Based on the research on tasks and required competences, two types of profiles of spatial data managers in local self-government with its specializations are proposed and described, which are recommended to be considered when developing both, occupation standard and qualification standard of spatial data managers.
\end{abstract}

Keywords: local-self-government; spatial data manager; spatial data manager competences; spatial data manager profile; qualification standards

\section{INTRODUCTION}

The aim of this paper is to analyse the profile of spatial data managers in local self-government units in the Republic of Croatia. A representative institution, the City of Požega, was chosen for this, which best reflects and shows the need for the occupation of such a profile, shows the activities performed in it, and are related to spatial data management. Furthermore, in accordance with the Methodology for the Development of Occupational Standards developed by the Ministry of Labor and Pension System, it is necessary to define the list of tasks covered by this occupation, and map them to the appropriate competencies required to perform these jobs. To connect the labor market and the education system, tasks and technical requirements and competencies are elaborated. Research shown in this paper is a support for the development of occupational standards of spatial data managers, which is necessary to develop an optimal qualification standard.

\section{DESCRIPTION OF INSTITUTION PROFILE (LOCAL SELF- GOVERNMENT)}

According to the Law on Local and Regional SelfGovernment [1], local self-government units can be municipalities or cities. Cities are all units with more than 10,000 inhabitants and county seats, and represent an urban, historical, natural, economic, and social common coverage.

There are 555 local self-government units in the Republic of Croatia, and the system of local self-government is characterized by an unbalanced structure. This large number of units contribute to this imbalance. An even bigger problem than the number of units is the fact that within each of these categories it is possible to find very small and very large units. Thus, there is a municipality with 137 inhabitants (Civljane), but also a municipality with almost 13,000 inhabitants (Čepin); among the cities there are those with less than 2,000 and those with almost 200,000 inhabitants. Split is 113 times larger than Komiža [2].

For municipalities, given the financial and other capacities, but also competencies, it is not realistic to expect that they will be an organization that develops a system with specialized experts for spatial information management. In municipalities, such mostly specific services are procured from external contractors, and for many jobs they rely on cooperation with regional self-government units (counties). Mostly, there are up to 10 employees of administrative character within one municipality. These are mainly social professions (economics, law), and very rarely they are technical professions.

The category of large cities can be emphasized as the most interesting category for analysis in this research. Large cities are the seats of counties and cities with more than 35,000 inhabitants. For this research, the representative organization which belongs to this category, City of Požega, was selected. Large cities have a very wide range of different authorities. in countries where local self-government developed mainly under the influence of the German tradition, including Croatia, public authorities and tasks performed by local self-government units can be classified into tasks from emerging from their own, self-governing, original scope, and state administration tasks transferred to local units, i.e. entrusted to local self-government [3].

Because of autonomy, and the ability to perform their own self-governing scope, large cities are the most dynamic organizations, which do not have such a large-scale and complex human resource structure as public administration, but on the other hand they perform a wide range of different tasks. In many cases, it can be said that they act both as private investors and as public bodies. Due to the characteristic number of employees (with the exception of the City of Zagreb, which has several thousand employees and is a large-scale organization, applying the analogy of categorizing the size of organizations in the Republic of Croatia for companies), employees of large cities are typically required to apply wider knowledge. A comparison of small and large organizations shows the existence of significant differences in several dimensions of their business. Large organizations are characterized by a global orientation and a rigid structure with a detailed and deep division of work tasks. A high degree of horizontal and vertical complexity, teamwork and professional management 
are also characteristics of large organizations. On the other hand, small organizations have a regional or local orientation, organic and flexible structures that are usually very simple, and entrepreneurs, i.e. most often the founders of the organization (in the context of this research: mayors), have strict control and hold key roles within the organization. Small organizations are characterized by jobs that have a wide range of activities and tasks to be performed, while in large organizations executors need to perform usually one or a smaller number of specialized tasks [4].

The scope of large cities is also determined by the Law on Local and Regional Self-Government. In their selfgoverning scope, they perform tasks of local significance that directly meet the needs of citizens, especially tasks related to: organization of settlements and housing; spatial and urban planning; communal economy; child care; social welfare; primary health care; upbringing and education; culture, sports; consumer protection; protection and improvement of the natural environment; fire and civil protection; traffic; maintenance of roads; construction and location permits, other acts related to construction, and implementation of spatial planning documents; and other activities in accordance with special law regulation.

To perform these tasks, the state-of-play is that the most common occupational profiles are social profiles, and to some extent also the profiles of the technical profession. As a support (backoffice), there is a need for a profile of experts in the field of information and communication technologies.

\section{SPATIAL DATA MANAGER PROFILE}

To properly define the profile of spatial data managers, within this research, the labor market is analyzed, which sets requirements for future staff. Business social networks and global employment portals, as well as the national labor market in the Republic of Croatia, were reviewed by searching published job vacancies through the official employment office, and well-known employment portals Moj-Posao.hr [5], and Posao.hr [6].

On the LinkedIn business social network [7], examples of job advertisements for vacancies such as Geospatial Data Analyst, Geospatial Data Manager, Geospatial Operations Analyst, GIS \& Location Analytics Manager can be found. In addition to the LinkedIn network, similar examples of job ads can be found on the global portal indeed.com, such as GIS Manager.

The profile of spatial data managers, and synonyms, in the world, from the analysis of processed job ads includes experts with the following common characteristics: technical background of education, skills in computer operations, work in GIS environment, knowledge of spatial data processing, soft skills - primarily communication.

Furthermore, on the employment portals in the Republic of Croatia, and on the official web portal of the Croatian Employment Service [8], for the following searches by keywords, the results do not appear or the results that appeared are not relevant (not related to spatial information management): spatial information management; GIS expert; spatial data manager; spatial data (for the purpose of expanding the search); geospatial. These keywords were searched in Croatian language as well.

Only for the keyword "geoinform" just one search result appears, which we can say is relevant - expert associate in the Department of Geoinformation System Development at the Central Bureau of Statistics. This shows that in the Republic of Croatia the profile of "spatial information manager" or "spatial data manager" is not recognized by employers.

State-of-play with a job positions in this profile is currently such that in the Republic of Croatia there are experts employed in local governments working on spatial information management, but these jobs are not formalized by systematization of work, or regulations on job titles, or regulations on internal organization. The formal names of these positions are more traditional, like geodetic expert, etc.

\section{KEY TASKS OF SPATIAL DATA MANAGER}

The tasks of spatial data managers in local selfgovernment could be categorized into several categories. As in all organizations, there are the most important basic tasks - key (core), then tasks that due to their knowledge, experience and competencies the employee performs, and background tasks that relate to the necessary tasks according to internal procedures of the organization. These background tasks consider certain records and reports about their own work, e.g. records of business trips. The subject of this research are just key (core) tasks which can further be categorized into several categories as well.

\subsection{Special Projects}

The basic task of the spatial data manager is establishing a spatial information management system for various purposes, as well as its maintenance and upgrade. Some examples of such works realized in the representative institution - City of Požega are: establishment of GIS for communal taxation; design and implementation of the Unified database of unclassified roads; establishment of a spatial register of real estate owned by local self-government unit; establishment of a cadastre of telecommunication lines with participation in negotiations; development of web applications for citizens; establishment of the Communal Infrastructure Register.

These are directly obligatory for local self-government units according to certain legal provisions. Thus, the establishment of a real estate register owned by local selfgovernment units is regulated by the Decree on the State Property Register [9], which regulations define the obligation for local self-government units in the development of real estate registers. Furthermore, the current state of technological development imposes the establishment of, no other than, a spatial real estate register in digital form. The establishment and maintenance of the Register of Communal Infrastructure is mandatory in accordance with the Law on Communal Economy [10]. The structure of the register is prescribed, i.e. the data that the register must contain are defined. The basic data in this case is the spatial reference in the form of the cadastral parcel. So, the logic to apply is also 
to establish indeed a spatial register in digital form. Local self-government units must establish and maintain a database of unclassified roads, in accordance with the obligation prescribed in the Law on Roads [11]. This database enables and simplifies the process of creating acts on city council regarding unclassified roads. This is an obligation under the same Law, but local self-governments are also encouraged to establish such a database with the propositions of various tenders for financing and co-financing of infrastructure investments. Therefore, without the list of roads in the formal Act, which arose from a database of unclassified roads, it is not possible to apply for investment co-financing in the construction of a particular road, and thus it has a direct impact on the development of the city.

There are also tasks that are not directly stipulated by law but are necessary for the practice of a good management of the city. An example is the establishment of a cadastre of telecommunications lines. Such a cadastre is necessary for the local self-government because it determines the condition of the length of telecommunication lines on cadastral parcels owned by the local self-government, and property relations and positive regulations stipulate that the local selfgovernment has the right-of-way compensation from the operator, or the owner of the telecommunication underground infrastructure. Some examples of the establishment of such a cadastre of telecommunication lines show positive consequence as a direct increase in revenue from compensation fees based on increasing the total length of lines for which it is paid for. The increase in representative institution was as much as $31 \mathrm{~km}$ [12].

All mentioned special project tasks are certainly a necessity for the realization of efficient management today for every local self-government unit, and their implementation is imposed with the inclusion, participation and guidance of the profile of spatial data managers.

At the same time, there is an issue that most of legal regulations do not explicitly state that prescribed registers and obligations consider that they are in fact spatial registers, although it is clear that all these databases contain entities located in space, and the main reason is to have an overview of them in georeferenced way. This fact is one of the obstacles in formalizing the occupational standards of spatial information or spatial data managers, and their recognition in the labor market by employers.

\subsection{Regular Tasks}

The key tasks of the spatial data manager, in addition to the above-mentioned special projects, also include regular daily tasks, which can be divided into several different types of tasks as in Tab. 1.

Repeating tasks are those everyday minor tasks that employee typically perform.

As the main work tasks in local self-government, various reports, reviews, and analysis generally appear. Given that a large part of the institution authorities can be related to spatial data management, the spatial data manager is mainly in charge of preparing and conducting analysis. He should have analytical and statistical skills. As with the above-mentioned repeating tasks, each of the analytical tasks is based on the obligations defined in the positive regulations of the Republic of Croatia.

Typically for technical staff in public administration, a significant part of the work tasks is related to the support of other departments in the organization. It has already been mentioned that in one local self-government it is possible to have various departments and sections as internal organizational units. For example, the Department of Finance, which keeps analytical records of assets as part of the balance sheet, regularly needs to provide excerpts from the Spatial Real Estate Register, given that real estate is the most valuable assets. Also, the up-to-date status of the Real Estate Registry is important to the Department of Finance because the value of the property has an impact on the credibility of the institution. Furthermore, when resolving ownership relations, and when disposing of real estate, the department that announces and conducts tenders must be served with data about characteristics for individual real estates (spatial-planning purpose, existence of infrastructure, zoning, etc.).

\begin{tabular}{|c|c|}
\hline Task type & Tasks examples \\
\hline \multirow{5}{*}{$\begin{array}{l}\text { Repeating } \\
\text { tasks }\end{array}$} & System maintenance-inserting new data, data updates \\
\hline & Forms development \\
\hline & Spatial planning procedures involvement \\
\hline & Asset management \\
\hline & Cadastral and land book procedures for the city \\
\hline \multirow{3}{*}{ Analytics } & Investment justification analysis \\
\hline & Report about state of space \\
\hline & Revision reports on ownership objects \\
\hline \multirow{4}{*}{$\begin{array}{l}\text { Support to } \\
\text { other } \\
\text { departments }\end{array}$} & Technical background design for EU funding applications \\
\hline & Different drawings and spatial maps creation \\
\hline & Preparing data (spatially related) for public procurement \\
\hline & $\begin{array}{l}\text { City council materials preparation (maps, visualizations, } \\
\text { etc.) }\end{array}$ \\
\hline \multirow{3}{*}{$\begin{array}{l}\text { Strategic level } \\
\quad \text { tasks }\end{array}$} & $\begin{array}{l}\text { Suggestions for National physical plan in prescribed } \\
\text { format (GML) }\end{array}$ \\
\hline & $\begin{array}{l}\text { Participating in development of Strategy for management } \\
\text { of city real estate }\end{array}$ \\
\hline & Participating in development of Traffic Masterplan \\
\hline \multirow{4}{*}{ Other tasks } & Negotiations with different external authorities \\
\hline & $\begin{array}{l}\begin{array}{l}\text { Acquiring different } \\
\text { construction }\end{array} \\
\end{array}$ \\
\hline & Coordination with building process stakeholders \\
\hline & External database inputs \\
\hline
\end{tabular}

An important task of spatial data managers in local selfgovernment is to participate in work at the strategic level. This requires knowledge of the situation in general, knowledge of public policies, and setting goals for the improvement of a certain part of processes under the authority of the organisation. This requires knowledge of the organization's capacity, as well as methodologies for drafting strategic documents, and knowledge of state-of-the-art technologies for drafting proposals for concrete measures, but also the necessary investment to solve identified problems. The strategic level considers the use of managerial skills and knowledge of the state of the profession even more than it requires technical skills. This shows, on the example of a city from the category of large cities, i.e. medium-sized organizations (see Chapter 2) that the spatial data manager in 
local self-government in the Republic of Croatia needs both, specific technical knowledge and narrow specialization, as well as broad management knowledge and soft skills.

\subsection{Categorization of Key Tasks by Required Competences}

To relate the occupation of spatial data manager in the local self-government and the tasks he or she performs, with the required qualifications, a categorization of key tasks with emphasized related competencies is created (Tab. 2).

For the categorization of tasks by required competences, the information from the City of Požega regular work processes were analysed. The documents, existing domain regulations, work systematization and work inputs and outputs were considered, and with deduction and experience of all authors based on the knowledge about work processes in similar organizations, and in City of Požega as sample organization, were synthetized to categories. The mapping process was not simple and straightforward. Certain tasks can belong to several categories, and in that case such a task is classified into a category according to its predominant characteristics and required competencies.

The categories by competences are divided into 1 . development, 2. Maintenance and upgrade, and 3. Usage and manipulation. Those categories are then mapped to required competences which are divided by the way of gaining the competence (Tab. 2).

Table 2 Categorization of tasks by competences

\begin{tabular}{|c|c|c|}
\hline $\begin{array}{l}\text { Category and } \\
\text { mapped type of }\end{array}$ & \multicolumn{2}{|c|}{ Competences gained through } \\
\hline \multirow[t]{2}{*}{$\begin{array}{l}\text { Development - } \\
4.1 \text { Special } \\
\text { Projects }\end{array}$} & $\begin{array}{l}\text { Existing } \\
\text { education } \\
\text { programmes }\end{array}$ & $\begin{array}{l}\text { General competences: Command of } \\
\text { computer usage, CAD and GIS } \\
\text { software usage, database } \\
\text { knowledge, spatial data processing, } \\
\text { knowledge of English } \\
\text { Specific competences: data } \\
\text { modelling, query language, } \\
\text { topological data processing, } \\
\text { knowledge of spatial data formats, } \\
\text { basic geodetic principles, } \\
\text { knowledge of spatial data } \\
\text { reliability, accuracy, and precision } \\
\text { Cartographic rules knowledge, } \\
\text { spatial referent systems }\end{array}$ \\
\hline & $\begin{array}{l}\text { Long-life } \\
\text { learning }\end{array}$ & $\begin{array}{l}\text { Knowledge of UML (both class } \\
\text { diagram and activity diagram), } \\
\text { computer networks basics, mapping } \\
\text { spatial data applicability in different } \\
\text { work processes, ability to interpret } \\
\text { correctly domain laws, fast } \\
\text { cost/benefit decisions on certain } \\
\text { operations, quality control methods, } \\
\text { familiarity with state-of-play and } \\
\text { state-of-art in geospatial } \\
\text { technology, familiarity with norms } \\
\text { and standards (OGC, ISO, } \\
\text { INSPIRE) }\end{array}$ \\
\hline $\begin{array}{l}\text { Maintenance and } \\
\text { upgrade - } \\
4.2 \text { Repeating } \\
\text { tasks - inserting } \\
\text { data }\end{array}$ & $\begin{array}{l}\text { Existing } \\
\text { education } \\
\text { programmes }\end{array}$ & $\begin{array}{l}\text { General competences: Command of } \\
\text { computer usage, CAD and GIS } \\
\text { software usage, database } \\
\text { knowledge, spatial data processing } \\
\text { Specific competences: } \\
\text { Cartographic rules knowledge, } \\
\text { topological data processing, spatial }\end{array}$ \\
\hline
\end{tabular}

\begin{tabular}{|c|c|c|}
\hline \multirow[t]{2}{*}{$\begin{array}{l}\text { Other tasks - } \\
\text { external database } \\
\text { integrations }\end{array}$} & & $\begin{array}{l}\text { data formats, basic geodetic } \\
\text { principles, knowledge of spatial } \\
\text { data reliability, accuracy, and } \\
\text { precision }\end{array}$ \\
\hline & $\begin{array}{l}\text { Long-life } \\
\text { learning }\end{array}$ & $\begin{array}{l}\text { Computer networks basics, } \\
\text { intermediate knowledge of web } \\
\text { technologies, ability to use API or } \\
\text { software plugins for web app } \\
\text { development }\end{array}$ \\
\hline \multirow[t]{2}{*}{$\begin{array}{l}\text { Usage and } \\
\text { manipulation - } \\
4.2 \text { Analytics, } \\
\text { Support to other } \\
\text { departments, } \\
\text { Strategic level } \\
\text { tasks, Other tasks }\end{array}$} & $\begin{array}{l}\text { Existing } \\
\text { education } \\
\text { programmes }\end{array}$ & $\begin{array}{l}\text { General competences: } \\
\text { Command of computer usage, CAD } \\
\text { and GIS software usage, good } \\
\text { command in MS Office package } \\
\text { Specific competences: } \\
\text { GIS analysis, multi-criteria } \\
\text { analysis, cartographic rules, } \\
\text { knowledge of SDI, ability to use } \\
\text { web services, basics of real } \\
\text { property evaluation methods }\end{array}$ \\
\hline & $\begin{array}{l}\text { Long-life } \\
\text { learning }\end{array}$ & $\begin{array}{l}\text { Statistics, data visualization skills, } \\
\text { knowledge of reporting rules, } \\
\text { orderliness, self-control methods, } \\
\text { ability to understand needs even } \\
\text { when they are not clearly } \\
\text { communicated by the superiors, } \\
\text { knowledge of regulations, good } \\
\text { knowledge of office administration } \\
\text { procedures, good knowledge of } \\
\text { organization of the state and public } \\
\text { institution division of authorities }\end{array}$ \\
\hline
\end{tabular}

\section{DISCUSSION}

Considering previous categories of tasks and required competences, for defining the profile of spatial data managers in local self-government, two possible theses appear - one is in the direction of creating a unique comprehensive profile, and the other is in the direction of specialization of the profile of spatial data managers in local self-government. From the analysis of required competencies and job descriptions presented in this paper, we conclude that two specializations are potentially possible - an engineer developer and an advanced user of spatial data.

\subsection{Unique Comprehensive Profile}

It is already clear that extensive and broad knowledge, an interdisciplinary approach to problem solving, and knowledge of various professions are required to perform spatial information management tasks in local selfgovernment units.

As an argument that supports this profile, it is possible to briefly describe the process of establishing the cadastre telecommunication lines under administrative area of the representative organization - City of Požega.

The City of Požega charges a fee for the establishment of right-of-way for telecommunication lines based on the valid Agreement with the operator, and based on the estimated length of lines, and a later supplement based on geodetic survey of existing lines. The task was to determine all lines laid under the ownership of City of Požega in order to determine the length or area of easement. Only after determining the existing situation based on available data, it 
will be possible to start arranging the relationship with the infrastructure operator with exact new numerical data.

In the procedure, it was necessary to recognize the need and define the project task, to know the methodology and architecture of the systems already established in the City administration, as prerequisites for this task.

The list of parcels with line lengths in the survey reports does not contain all parcels owned by the City on which the lines are, due to the passage of time and other circumstances. In the overall procedure, the person who manages the spatial information in the City of Požega recognized the need to update the list of lines based on the same survey reports. Furthermore, it was necessary to analyse and process the input data of survey reports, created by classical geodetic survey and present in the classical dwg files, with corresponding Excel tables.

In the process, the input spatial data were in the HDKS (old Croatian official coordinate reference system) and it was necessary to know and operationally carry out the process of transformation into the new coordinate system HTRS96 (Croatian Terrestrial Reference System 1996 - new official CRS), using the software which is available in the organization. After processing the input data, the next step was to conduct GIS analysis and spatial intersection of several layers with selected entities that were previously defined. Through the process, it was necessary to identify and appropriately address special cases such as the mismatch of the administrative border and the border of the cadastral municipality which do not always coincide, and cases in which parts of one cadastral parcel represent several different categories of roads (i. e. they are under different regimes). This presupposes knowledge of various areas and road management, and administrative arrangements, and regulations of land registry law and the establishment of easements. From the completed task, it was further necessary to create a clear report, and a clear list of telecommunication lines to update the easement agreement with the operator, so that the same report is a clear proof and basis for clear and effective communication in negotiations with the operator. The spatial data manager was in charge of approaching the telecom operator in negotiations as well.

The whole described process of this single example, argues in favour of defining a unique profile of managers who should have almost all the competencies that can be found in Chapter 4.3, i.e. to know classical geodesy, GIS analytics, model and structure of other related systems, to widely know the regulations of many technical and other areas in order to link and recognize the need to carry out this task, the ability to decide and choose the methodology, to actively use GIS tools to implement the process, the ability to compile concise report, communicate and negotiate for a complete process leading to the final result, which is increase of revenue.

\subsection{Specialization of the Profile of Spatial Data Manager}

Considering the task categories from Chapter 4.3, and the necessary competencies, we can conclude that it is possible to develop two specializations of the spatial data manager profile.

\subsubsection{Advanced User of Spatial Data}

The first specialization could be called "advanced user of spatial data in local self-government". This specialization is characterized by tasks which could be defined as maintenance and upgrade, as well as use and manipulation tasks. It is clear that these categories have in common a group of competencies, in fact the traditional, classical geodetic group of competencies - CAD and GIS software, knowledge of the basics of geodetic principles, understanding of reliability, accuracy and precision of certain spatial data, skills in other software which are widely used such as Excel, and to a certain extent the basics of computer networking and the basics of web technologies, which are the skills that are acquired at the basic level on higher education institution (faculty). This specialization of spatial data managers is more oriented to the usage and manipulation of already established spatial information management systems, but in various applications. This type of professional acts more as a service staff who serves and provides support to other areas of authorities in the local self-government.

\subsubsection{Engineer Developer}

This specialization is characterized with knowledge specific for modern studies of geoinformatics (with emphasis on informatics and data modelling). The engineer developer has the role of developing new spatial information systems. He also needs to have a broad knowledge of different areas, to be able to connect needs, rules, and final solutions that bring improvement of work processes. It is not so crucial to know the classical geodetic principles for this specialization. For development, the emphasis is on the database, and on data modelling, not just class modelling, but also workflow diagrams, as well as knowledge of higher geodesy. It is necessary to know the standards and norms, and to have the way of thinking at the program and strategic level.

\subsection{Forming (Educating) Spatial Data Manager}

From the conducted analysis, it is evident that the profile of spatial data managers by the name is not recognized by employers in the Republic of Croatia. This leads to a mismatch between supply and demand in the labor market. The employers have the need for the experts with competences of this kind, which is proven with wide range of tasks described in Chapter 4., but still, they do not have common information about what kind of qualification degree which would comprehend all the necessary competences should they seek.

The process of modernization and reform of the qualification system in the Republic of Croatia is carried out through the Croatian Qualifications Framework - CROQF [13], which establishes a mechanism for recognizing the mismatch between supply and demand for workers at the level of competencies.

In order to harmonize the supply and demand on the labor market in accordance with the CROQF related to the geodesy and geoinformatics sector, i.e. the area of spatial 
information or data management, it is necessary for employers to recognize the possibilities of this profile of employees and to develop occupational standards. From that, it is then possible to develop a qualification standard for the profile of spatial data manager, or its specialization.

Occupational standards and qualification standards have been introduced in Croatia through the CROQF, which can cover all levels of education. The Occupational Standard is defined by law as a list of all jobs performed by an individual in a particular occupation and a list of competencies required for their successful performance, while the Qualification Standard is defined as the content and structure of a particular qualification. It includes all the information needed to determine the level, scope and profile of the qualification and the information needed to ensure and improve the quality of the qualification standard. According to the Rulebook on the CROQF Registry, the occupation standard contains a list of key jobs in one or more jobs that define the occupation and associated individual competencies and a list of sets of competencies and related individual competencies required to work in one or more jobs. Therefore, occupational standards should contain a list of key tasks and a corresponding list of competencies, and a list of competency sets with associated individual competencies required in a particular occupation [14]. From this it is further possible to develop a standard of qualifications.

In order to develop qualification standards for spatial data managers in local self-government, it is necessary to monitor the necessary competencies, and take into account the fact of the need to increase the importance of informatics in the coin "geoinformatics" or "geomatics". Also, the spatial data manager is a multidisciplinary occupation. There is a strong focus on new technologies and the need to gain knowledge, especially the fast-growing Industry 4.0 (Cloud, Internet of Things, Big Data, Artificial Intelligence), and new $5 \mathrm{G}$ technologies. These topics will certainly need to be addressed when developing the qualification standards of spatial data managers in the local self-government, otherwise the developed qualification standard will become obsolete at the same moment when it is defined.

Recently, because of the digital transformation process, the activities in local self-government units on the development of smart cities (SmartCity concept) has intensified. The solutions commonly applied in the transformation of cities into smart cities, mainly relate to information systems with a spatial component, because space is the largest and most important resource available and managed by a city. In this trend, geodetic and geoinformatics experts can see the opportunity and apply their knowledge and increase the share of their activities within the system of local self-government units, unlike the previous paradigm of geodetic staff, where the largest share of professional geodetic and geoinformatics staff worked in the state administration, i. e. the cadastre [15].

Accordingly, great significance in the future education and qualification standard of spatial data managers needs to be given to technologies belonging to Industry 4.0.

Finally, the strategic framework in the Republic of Croatia defines the need for new qualification standard development harmonized with the needs in economy. Smart Specialization Strategy (S3) [16] is an integrated strategic document for economic transformation of Croatia based on new emerging technologies and innovation. That document mentions that lack of skilled labor is the second most significant obstacle to innovation, although only $44 \%$ Croatian companies acknowledge that they have difficulty finding a skilled workforce. According to the study, employees often have a lack of experience $(80 \%)$ or the education system does not allow them to acquire the necessary skills $(40 \%)$. In terms of human resources, the Republic of Croatia is going through a difficult and slow transition, primarily due to the recession created long-term unemployment and reduced the relevance of workers 'skills also due to very slow reforms of the education system that continues to produce qualifications that are not in line with labor market needs. Combined with low investment in lifelong learning in general, skills structure has become a limiting factor for the development of competitiveness, innovation and growth. The conclusion is that there are not enough study programs, i. e. qualification standards for the adequate occupations of the new modern employer's needs.

Furthermore, Industrial Strategy of the Republic of Croatia [17], as the second priority defines encouraging strategic cooperation between industry and the education system, science and technology. Knowledge, skills and abilities of human resources are the basis for achieving a competitive advantage of companies, industry and economy. The greatest contribution to the development of industry and the economy of the state can be made through a quality education system. The basis for attracting any investment, with a stable political and macroeconomic environment, lies in the availability of an educated workforce. It is important that the state directs investments in the education system in areas that are important and necessary for the future needs of industry development. Given the rapid and frequent changes that occur in the environment, and thus create a continuous need for new knowledge and skills, it is extremely important that the education system "collects" information from the environment and industry and continuously adapts the education system to new knowledge needs, with the aim of encouraging new employment through new knowledge.

The Strategy for Education, Science and Technology [18] as primary goal for high education stipulates the need to harmonize the number and profile of study programs social and economic needs.

Forming (educating) the spatial data manager, i. e. development of qualification standard for spatial data manager is in line with all those strategic documents.

\section{CONCLUSION}

Local self-government units in the Republic of Croatia are characterized by quite heterogeneous internal structures. Nonetheless, they all share a wide range of different authorities. The most important activities which are conducted within authorities are related with spatial management as the most important resource of a city or municipality. Accordingly, there is the need for qualified staff for spatial information management. In the Republic of Croatia, such staff as a spatial data manager is not clearly recognized by employers, despite the fact that such qualified staff "covers" many tasks, from special projects to 
establishing certain spatial data management systems, analytical work, data service support and information for other departments within the local government, to work at the strategic and program level. The employers evidently have the need for human resources with this kind of competences, but it is not clear for them which formal qualification degree should they seek.

It is important to point out that the categorization, but also the nature of tasks due to the autonomy and heterogeneity of local government can be different. This research presented a realistic comprehensive example of tasks and work processes involving staff who can identify with the future spatial data manager. For the efficient development of standards for the qualifications of spatial data managers in the higher education system, it is necessary to consider the highlighted needed competencies, and to develop a standard of occupation. It should be noted that the interdisciplinarity is a common feature of all tasks of spatial data managers. It is necessary to cooperate across various professions and areas to achieve comprehensive approach. The essential competencies of thinking at the strategic level, reporting rules, data modelling and process flow, and familiarity with many related mainly technical professions, as well as strong knowledge and law interpretation skills, are emphasized as a novelty in the required competencies list.

In the future education and design of qualification standard of spatial data managers, 4.0 Industry themes should be significantly represented since geodetic profession is by nature technologically oriented and technologically advanced. Moreover, the geodetic profession is intensively developing in the direction of emphasis on geoinformatics, or geomatics.

Ultimately, by setting up spatial registers and the right approach in using existing data and available spatial information management technology, it is possible to achieve direct effects of increasing revenues for budgets, as shown by one example. This indicator clearly proves the need for today's trends in local self-government units to go in the same direction, which is regular structuring of existing data into spatial registers in order to directly contribute to the budget with the help of GIS spatial information management technology. Finally, financial benefit is the strongest argument for decision makers. All tasks that belong to the domain of spatial data managers in local self-government either contribute directly to the financial benefit for budgets, or are conditioned by mandatory regulations, and therefore the recognition of spatial data managers in local selfgovernments and occupation standard development should not be difficult to realize.

\section{REFERENCES}

[1] Official Gazette: Law on Local and Regional Self-Government (OG 33/01, 60/01, 129/05, 109/07, 125/08, 36/09, 36/09, $150 / 11,144 / 12,19 / 13,137 / 15,123 / 17,98 / 19)$

[2] Koprić, I. (2010). Karakteristke sustava lokalne samouprave u Hrvatskoj - The characteristics of local self-government system in Croatia. Hrvatska javna uprava, 10(2).
[3] Koprić, I. (2005). Djelokrug lokalne i područne (regionalne) samouprave - Local and Regional Scope of Affairs. Hrvatska javna uprava, 5(1).

[4] Hernaus, T. \& Aleksić, A. (2015). Unutarnji čimbenici organizacije. https://doi.org/10.13140/RG.2.1.3203.6328

[5] www.moj-posao.hr, accessed 7.1.2020.

[6] www.posao.hr, accessed 7.1.2020.

[7] www.linkedin.com/jobs, accessed 7.1.2020.

[8] https://burzarada.hzz.hr/Posloprimac_RadnaMjesta.aspx, accessed 7.1.2020.

[9] Official Gazette: Decree on the State Property Register (OG $55 / 11)$

[10] Official Gazette: Law on Communal Economy (OG 68/18, $110 / 18)$

[11] Official Gazette: Law on Roads (OG 84/11, 22/13, 54/13, 148/13, 92/14, 110/19)

[12] Lisjak, J., Cetl, V., \& Ljulj, K. (2017). Prostorni registri u službi ekonomske učinkovitosti - povećanje prihoda od naknade za služnost - Spatial registers for economic efficiency - increase of income from compensation for right-of-way for utilities. Proceedings of the $10^{\text {th }}$ Symposium of Chartered Geodetic Engineers, Opatija.

[13] http://www.kvalifikacije.hr/, accessed 2.11.2020.

[14] Ministry of Labor and Pension System: Methodology for developing occupational standards

[15] Cetl, V., Markovinović, D., \& Lisjak, J. (2019). Digitalna transformacija u geodetsko-geoinformatičkoj struci - Digital transformation in geodetic-geoinformatic profession. Proceedings of the $12^{\text {th }}$ Symposium of Chartered Geodetic Engineers, Opatija.

[16] Smart Specialization Strategy of the Republic of Croatia 2016.2020., https://strukturnifondovi.hr/wp-content/uploads/ 2017/03/Strategija-pametne-specijalizacije-RH-2016.2020.pdf, accessed 20.2.2021.

[17] Industrial Strategy of the Republic of Croatia 2016. - 2020., https://vlada.gov.hr/UserDocsImages/2016/Sjednice/2014/182 $\% 20$ sjednica $\% 20$ Vlade/182\%20-\%201.pdf, accessed 20.2.2021.

[18] Strategy for Education, Science and Technology, https://mzo.gov.hr/UserDocsImages//dokumenti/Obrazovanje/ /Strategy\%20for\%20Education,\%20Science\%20and\%20Tehn ology.pdf, accessed 20.2.2021.

\section{Authors' contacts: \\ Josip Lisjak, MSc \\ (Corresponding author) \\ City of Požega, \\ Trg Svetog Trojstva 1, HR-34000 Požega, Croatia \\ E-mail: josip.lisjak@pozega.hr}

Ante Rončević, Associate Professor PhD University North, University Center Varaždin, Jurja Križanića 31b, HR-42000 Varaždin, Croatia

E-mail: aroncevic@unin.hr

Danko Markovinović, Assistant Professor PhD University North, University Center Varaždin, Jurja Križanića 31b, HR-42000 Varaždin, Croatia E-mail: danko.markovinovic@unin.hr 